\title{
They stole my baby's soul: narratives of embodiment and loss
}

\author{
A V Campbell, M Willis
}

J Med Ethics; Medical Humanities 2005;31:101-104. doi: 10.1136/jmh.2005.000215

The controversy over retained organs, arising from the Bristol and Alder Hey findings about postmortem uses of body parts, has revealed a gulf between medical and lay understandings of the human body and its relationship with the human person. There is a clear utility in having a "doctor's story", which is different from the way patients and their families understand the significance of the body, since this enables medical diagnosis and treatment to be effective. When, however, the medical narrative intrudes uncritically into areas where the key issue is the integration of the body with the person, experienced or remembered, things go badly wrong with communications in medicine. For the lay person disrespectful treatment of the body of a loved one represents a personal attack. In this respect, strong emotion, seen as irrelevant or distracting by scientific medicine, is a central aspect of the narrative concerned with loss of a loved person. For doctor and lay person alike, a narrative of the self which pays proper attention to the embodiment of the self, offers the possibility of a genuinely humane medicine.

See end of article for authors' affiliations

...................

Correspondence to: ProfessorAlastairVCampbell, Centre for Ethics in Medicine, 73 St Michael's Hill, Bristol BS9 4DT, UK; Alastair.Campbell@bristol. ac.uk

Received 10 May 2005 Accepted for publication 15 August 2005 (Alastair) was appointed vice chair of the commission. A year earlier, Alastair had suffered the loss of a daughter, who died of cancer at the age of 36. At his daughter's request, an autopsy was performed. (She wanted to have the efficacy of the complementary therapy she had used tested.) Her organs were not retained after the autopsy. For the authors, as for most other members of the commission, the powerful emotions generated by this controversy were an unforgettable experience. Commission meetings were held in public, and on several occasions the anger and grief of affected families interrupted proceedings or brought them to a halt. Pathologists were described as "butchers", comparisons were made with the holocaust, and the of a cover up and of complicity in professional wrongdoing.

This paper seeks to explore the roots of this powerful reaction to the widespread practice of retaining organs and tissue without the knowledge and consent of relatives. We suggest that we see here two different narratives, the professional story and the family story, narratives so different that the narrators simply talk past each other. The inquiries revealed unbridgeable differences in understanding between the professionals and the bereaved families. This showed a failure of communication, beneath which, we suggest, lay the dualistic approach of scientific medicine, with its treatment of the body as an object of study. The lay (non-medical) view of the body is quite different from the medical one. In the lay view bodies are seen as integral to persons, though also often distinguished from them-for example, when the person no longer seems present after a major brain injury- "It doesn't seem like him any more". Even when the person seems to have "left the body", however, the mortal remains form a powerful reminder of the person once intimately known. For this reason, the unconsented removal of parts of a dead body is seen as an attack on a lost loved one and as an affront to the feelings of those who mourn the dead. We shall argue below that a richer understanding-one which acknowledges the significance of such "embodied selves" in peoples' stories of their lives and in the lives of those they love-will serve medicine much more adequately than over-rationalistic accounts, which see the body as merely a container for consciousness.

\section{Two narratives in non-communication} In Doctors' Stories Kathryn Hunter describes what she calls the "narrative incommensurability" of doctors' and patients' accounts of illness: commission members themselves were accused
The patient's account of illness and the medical version of that account are fundamentally, irreducibly different narratives, and this difference is essential to the work of medical care. Sick people who seek a physician's advice and help are in quest of exactly this difference, for, physicians are believed not only to know more about the body but also to see its disorders clearly and without shame. Yet because it is scarcely acknowledged by either patient or physician, the difference between their accounts of the patient's malady can warp understanding between them. ${ }^{3}$ 
As we see from this quotation, Hunter is not deploring the fact that the narratives are incommensurable-she sees this as necessary if medicine is to offer help to the patient. Things go wrong, however, when the difference between the narratives is not acknowledged and understood, and this wrong is compounded, when, as in the retained organs controversy, the medical narrative persists past the point where it is either necessary or useful.

Let us compare, then, the way relatives saw the retention of organs after postmortem examination with how it was conceptualised by some of the professional bodies, who gave evidence to the Chief Medical Officer's Summit on Organ Retention. The evidence of relatives is fully available from the documentation of the summit and also from the two inquiry reports of Bristol and Alder Hey. We can give only a few brief excerpts to convey the profound feelings experienced by so many families:

To take all Stephen's organs from his body and store them for ten years without establishing a definitive cause of death is unacceptable. His parents buried him ten years ago as a shell. It is like grave robbing before being put in the grave. His body had been mutilated (Royal Liverpool Children's Inquiry, ${ }^{2}$ p 436).

You relive the moment that she died over and over again. I have flashbacks of what they have done and what you imagine they have done. I had a dream the other day that I said to someone in the hospital where I work "what is in the cupboard". When we opened it there were three jars: one with babies' hearts, one with babies' lungs and one which looked like peas. When I looked closer they were eyes...I have a great big empty void inside (Royal Liverpool Children's Inquiry, ${ }^{2}$ p 421).

...they were devastated to hear that their daughter's tongue had been retained, and the father protested silently outside Alder Hey... They describe the hospital as having stolen their daughter's body, which was white as driven snow. It was reduced to skin and bone by predators and it must never happen again (Royal Liverpool Children's Inquiry, ${ }^{2} \mathrm{p}$ 421).

She is emotional for several reasons. The first is the deceit involved. She did not know what had happened to her daughter or that she had been desecrated. Alexandra had been stripped bare of everything and somebody believed they had the right to do it and to return her apparently complete for funeral purposes but in fact without her internal organs. For five years she believed Alexandra was intact and at rest (Royal Liverpool Children's Inquiry, p 408).

The worst aspect, I mean, it is an awful trauma having Bethan operated on. The one thing as a father one enjoys is having a sense of control over your son's life, but then with the operation, you lose that control, but then to further lose that control after death in this way is so upsetting (Bristol Royal Infirmary Inquiry, ${ }^{1}$ p 39).

Compare this testimony from relatives with some of the written evidence given by professional medical associations to the CMO's summit:

The fact that in the past many families have not been informed in detail about what a postmortem examination entails... invariably reflected a simple and understandable wish to spare them further anguish and distress at the time of bereavement (Royal College of Pathologists) (Department of Health, ${ }^{4}$ ref 101).
The Royal College of Surgeons deprecates the retention of organs and tissues following postmortem examinations or surgical operations without appropriate informed consent having been given.

The college believes that sensible measures should be introduced to allow for the continuance of retention of organs and tissues for scientific research and for teaching purposes (Department of Health, ${ }^{4}$ ref 107).

It must be recognised that the retention of organs and tissues has been common practice, world wide, for centuries, and has formed an essential part of medical education and research, both undergraduate and postgraduate. The frequency of autopsy has declined over the past two decades to the detriment of education, and further obstacles to the use of autopsy are to be deplored. It is also regrettable that there have been implications that such storage of organs and tissues has been thoughtless, cavalier or macabre (Royal College of Physicians) (Department of Health, ${ }^{4}$ ref 222).

It is perhaps a paradox that in an age when we have more understanding than ever before of the nature of human life and the biology of the human body, we are more distressed than at any time in human history about what is perceived as inappropriate disposal of the whole human body or part of it...This is a philosophical puzzle...(President, Royal College of Paediatrics and Child Health) (Department of Health, ${ }^{4}$ ref 119).

Perhaps this last quotation is the most powerful indication of the narrative dissonance of the medical and lay understandings of the body. The president of the Royal College of Paediatrics and Child Health cannot understand how, with such improved knowledge of the biology of the body, relatives can feel distressed when they discover that they have buried a body "stripped of organs". We see similar bewilderment among the physicians and surgeons, to whom the most important thing is the medical progress made possible by organ retention. The pathologists worry that the good intentions of the past (not to cause distress) will be overlooked. This is the medical story: it simply creates a different world from that of the grieving and angry relatives.

Such a clash of narratives is not restricted to the medical world. The philosopher, John Harris, shows similar puzzlement and disapproval, when considering the controversy over organ retention and the proposals for a more respectful treatment of human remains:

A quite absurd, if understandable, preoccupation with reverence and respect for bodily tissue has come to dominate discussions of retained tissues and organs in the wake of the Alder Hey revelations. We do not normally feel this reverence for our bodily remains, tissue and organs when alive-why suddenly this morbid postmortem preoccupation ${ }^{5}$

Harris's disrespect for respect in this situation stems from his commitment to a valuation of human life in terms of identity based on consciousness. He shares this with the philosopher John Locke, who gave an account of human identity based solely on awareness and memory. Such a view leaves no room for the significance of the body, though it lends itself well to the scientific paradigm on which medical practice is usually based. (One of us, Alastair, has explored this problem with John Harris's view of the body at greater length in a chapter in a forthcoming book entitled "Why the body matters: reflections on John Harris's account of organ procurement" ${ }^{6}$ ) 
Embodiment, vulnerability, and loss

It would be naïve to suppose that these two discourses can easily be reconciled. Indeed there is no need to do so, provided we understand that they serve different purposes. The medical discourse is functional for achieving the goals of scientific medicine, in which the body as object is required in order to create the generalisations that allow for differential diagnosis and (some kinds of) therapeutic intervention. Even in the realm of the living, however, it is now well recognised that such distancing and objectifying of the body has detrimental effects on health, and offers only limited scope for effective recovery from illness.

When medicine extends uncritically into the realm of the dead and supposes that "this malformed and damaged heart" (to be stored in a jar for further study) is the same as "my child's heart" (soon to be buried with my child's body), then it loses the plot completely. But, due to the god like status that society has accorded doctors, the scientific account of the body becomes the only "rational" one. The meanings attributed to the parts of the body by doctors and by the lay public are in reality completely different, and each has its own rationality. Intimate relationships never concern merely a meeting of minds or of Lockean self valuing pools of consciousness! The physical body of the person loved is fully part of the love that parent feels for child or wife for husband. This embodiment of the person does not suddenly disappear in death, though, of course, it soon becomes necessary to let go of the body and live only with the memory and mental images of the person now dead. A mother cuddling her dead child, a husband kissing the cold brow of his wife's dead body, are not acts which deny the death of the person. They are part of the story of human lives shared and of the pain which comes from parting.

For these reasons, we believe that the narrative that best explains why unconsented organ retention was such an affront is one that focuses on embodiment of the self. In speaking of "embodiment" we refer not just to issues concerned with respect for the dead, but also with the way in which we experience ourselves, other selves, and the world around us. These experiences of embodiment are characterised by closeness, vulnerability, and loss.

\section{Emotions, the body, and the narrative self}

At this point in our discussion some lines from a poem of Philip Larkin's come to mind:

\section{I would not dare \\ Console you if I could. What can be said, \\ Except that suffering is exact, but where \\ Desire takes charge, readings will grow erratic? ${ }^{7}$}

The striking contrast between the philosophical and medical narratives about the treatment of the bodies of the dead and the lay narratives of the same events stems from the centrality of emotion in personal relationships. In the retained organs controversy, families were criticised for letting their feelings run away with them, and it was suggested that the media were deliberately manipulating emotions to get a good story, with headlines such as "They stole my baby's soul". According to The Times, this outpouring of emotion badly damaged medicine:

The body parts furore triggered an irrational and emotional backlash against pathology and organ donation, the effects of which are still being felt. A recent survey published in New Scientist found that one in ten pathology posts is vacant, as doctors shy away from joining a profession so widely caricatured as ghoulish. ${ }^{8}$
So now the families, traumatised by the deception and concealment of the organs controversy, must bear the blame for the problems of pathology! This moral condemnation is echoed in John Harris's description of opposition to the use of organs as "wicked". ${ }^{9}$ Clearly, emotions can blind our better judgment at times and some powerful emotional reactions can have their own momentum, in which the wholeness of the self is engulfed and our identity lost. But without emotion we are no selves at all. We become distanced from our body and unable to create personal relationships or respond to the lives of others. It is as much the continuity of emotion as the continuity of memory and consciousness that gives us that unique phenomenon we call personal identity.

The neurophysiologist, Antonio Damasio, in a work criticising the influence of the mind/body dualism of Descartes on modern medicine, has written powerfully about how it is emotion that gives us our distinctive identity as humans:

\begin{abstract}
At first glance there is nothing distinctively human about emotions, since it is clear that so many non-human creatures have emotions in abundance; and yet there is something quite distinctive about the way in which emotions have become connected to the complex ideas, values, principles and judgments that only humans can have, and in that connection lies our legitimate sense that human emotion is special. Human emotion is not just about sexual pleasures or the fear of snakes. It is also about the horror of witnessing suffering and about the satisfaction of seeing justice served; about delight at the sensuous smile of Jeanne Moreau or the thick beauty of words and ideas in Shakespeare's verse; about the world weary voice of Dietrich Fischer-Dieskau singing Bach's Ich habe genug... ${ }^{10}$
\end{abstract}

So, reading again the narratives of the affected relatives, we can see how it is the emotional loading of the memory that makes it distinctively and painfully theirs: the dreadful images of the body as an empty shell; of the horrifying cupboard full of specimens that once were hearts or eyes of living babies; the depredation of a daughter's white body; the anger at the removal of a dead child's tongue, and the sense of loss of control, when you can do nothing to protect your own child. These are all the responses of people in close human relationships.

It is pointless to suggest that these narratives of anger, grief, and loss are one sided or irrational. They are what they are: the living memory of emotional trauma, which will be forever part of the identity of those experiencing them. There is no "real" or "better" or "more rational" self, floating above the emotions of our daily bodily lives. There is only the lived self and there is only the one narrative of our bodily experiences, a narrative that is ours alone.

\section{CONCLUSION}

\section{Embodiment and medicine}

So what might this all mean for the practice of medicine? At one level, the retained organs controversy has brought to the fore some much needed changes in medical practice. New legislation should ensure that the removal and use of organs without consent cannot happen again. The powerful reaction of relatives to the discovery of retention has also brought about changes in medical practice, with a better understanding of how to help people facing the trauma of bereavement. But at a deeper level there is probably still a long way to go, before medicine can rediscover the lost dimension of embodiment. This entails seeing the strength, but also the limitation, of the "scientific" approach to medical practice. It requires the ability 
to respond to the emotional and not merely the physical aspects of people's lives.

A good place to start will be in the training and practice of doctors themselves, enabling them to reflect on their own embodiment. Medical training is beginning to respond to the demand that it produce doctors with a richer understanding of the whole person in medicine. For example, Jaye ${ }^{11}$ reports on the responses of general practitioners, who were introduced to the concept of embodiment as part of a postgraduate course in medical anthropology. One of the most interesting responses came from a practitioner, who realised that medical training and practice had distanced her from her own body, to the extent that she failed to recognise even her own need for medical care:

There wasn't time to think, there wasn't time to...be compassionate, you didn't have time to get to know people, you were running to physically keep up...I knew I had asthma, but I didn't realise that's what was doing it and I couldn't understand why I felt exhausted all the time...I felt numb, I did feel distanced from my own body...I think you become less human. And you didn't expect to see yourself as human (Jaye, ${ }^{11} \mathrm{p} 44$ ).

These telling words illustrate how the objectification of the patient's body, which scientific medicine encourages, can affect the practitioner's own bodily life to an almost lethal extent. Allowing the medical narrative to include an awareness of the doctor's own bodily reactions might indeed transform medical practice. It could be a meeting place for the medical and lay narratives at those times in medical practice when what the patient or family needs is a humane understanding of a shared vulnerability. We need to recover the wisdom of the old adage: physician, heal thyself.

\section{Authors' affiliations}

A V Campbell, Centre for Ethics in Medicine, University of Bristol, Bristol, UK

M Willis, National Bereavement Partnership, London

\section{REFERENCES}

1 Bristol Royal Infirmary Inquiry. Interim report of the Bristol Royal Infirmary inquiry. London: Central Office of Information, May, 2000.

2 Royal Liverpool Children's Inquiry. Report of the Royal Liverpool Children's inquiry. London: Stationery Office, 2001.

3 Hunter KM. Doctors' stories: the narrative structure of medical knowledge. Princeton: Princeton University Press, 1991:123.

4 Chief Medical Officer's Summit on Organ Retention. Evidence documentation. London: Department of Health, 2001.

5 Harris J. Law and regulation of retained organs: the ethical issues. Leg Stud 2002;22:527-49.

6 Campbell AV. Why the body matters: reflections on John Harris's account of organ procurement. In: S Holm, Hayry M, Takala T, eds. Life of value. Amsterdam and New York: Rodopi (in press).

7 Larkin P. Deceptions, collected poems. London: The Marvell Press, 1988:32.

8 Times, 2003 Dec 6.

9 Harris J. Organ procurement: dead interests, living needs. J Med Ethics 2003;29:130-4 at 133 .

10 Damasio A. The feeling of what happens. London: Vintage, 2000:22.

11 Jaye C. Talking around embodiment: the views of GPs following participation in medical anthropology courses. J Med Ethics: Medical Humanities 2004;30:41-8.

\section{bmjupdates+}

bmjupdates+ is a unique and free alerting service, designed to keep you up to date with the medical literature that is truly important to your practice.

bmjupdates+ will alert you to important new research and will provide you with the best new evidence concerning important advances in health care, tailored to your medical interests and time demands.

Where does the information come from?

bmjupdates+ applies an expert critical appraisal filter to over 100 top medical journals A panel of over 2000 physicians find the few 'must read' studies for each area of clinical interest

Sign up to receive your tailored email alerts, searching access and more...

www.bmjupdates.com 